\title{
Performance of zero water discharge (ZWD) system with nitrifying bacteria $B$. megaterium and microalgae $C$. calcitrans components in super intensive Pacific white shrimp Litopenaeus vannamei culture at low salinity
}

\section{Kinerja sistem zero-water discharge (ZWD) dengan komponen bakteri nitrifikasi, $B$. megaterium dan mikroalga $C$. calcitrans pada budidaya udang putih Litopenaeus vannamei superintensif besalinitas rendah}

\author{
Rahim $^{1 *}$, Gede Suantika ${ }^{2}$, Harish Muhammad ${ }^{2}$ \\ 'Fishery Studies Program, Faculty of Agriculture, Fisheries and Animal Husbandry, \\ University of Sembilanbelas November Kolaka, Jl. Pemuda 339, Kolaka 93562 \\ ${ }^{2}$ Microbial Research Biotechnology Group, School of Life Sciences and Technology, Bandung Institute of \\ Technology (ITB), Jl. Ganesha 10, Bandung 40132 \\ *Email : rahimspimsi@gmail.com
}

(Received July 4, 2017; Accepted July 26, 2018)

\begin{abstract}
This research aimed to obtain the performance of super intensive white shrimp rearing using zero water discharge (ZWD) system. This study consisted of four steps, (1) activation and cultivation of nitrifying bacteria, microalgae C. calcitrans and B. megaterium; (2) acclimatization of Pacific white shrimp PL10 with $30 \mathrm{~g} / \mathrm{L}$ of salinity and decreasing salinity at 2-3 g/L/day; (3) conditioning of ZWD system; (4) white shrimp rearing in $400 \mathrm{~L}$ of tank for ten weeks. The experiment used three treatments, (a) shrimp reared without any addition of microbial agent with water exchange conducted every week as much as 10-20\% of total rearing volume as control (K); (b) ZWD systems with the applications of nitrifying bacteria, (C. calcitrans and B. megaterium) without water discharge (P1); and (c) ZWD system with the application of microalgae $C$. calcitrans and B. megaterum without water discharge (P2). According to the results, application of nitrifying bacteria, microalgae $C$. calcitrans and B. megaterium were able to improve the performance of ZWD system performance of white shrimp rearing at low salinity. In addition, the ZWD system was also able to increase the growth rate and survival rate of shrimp when it compared to control. The best rearing performance was found in ZWD system with application of microalgae $C$. calcitrans and $B$. megaterium.
\end{abstract}

Keywords: Litopenaeus vannamei, ZWD, low salinity, microalgae, nitrification bacteria.

\begin{abstract}
ABSTRAK
Penelitian ini bertujuan untuk mengetahui kinerja budidaya udang putih super intensif bersalinitas rendah menggunakan sistem zero water discharge (ZWD). Penelitian ini terbagi dalam tiga, yaitu (1) aktivasi dan kultur bakteri nitrifikasi, mikroalga $C$. calcitrans dan B. megaterium; (2) aklimatisasi udang putih PL10 salinitas $30 \mathrm{~g} / \mathrm{L}$ dan penurunan salinitas 2-3 g/L/hari; (3) pengondisian dari sistem ZWD; (4) pemeliharaan udang putih selama 10 minggu di bak bervolume 400 L. Penelitian ini menggunakan tiga perlakuan ; (a) perlakuan kontrol tanpa penambahan mikroba dan pergantian air setiap minggu sebanyak 10-20\% (K) ; (b) sistem ZWD dengan bakteri nitrifikasi, mikroalga $C$. calcitrans dan B. megaterium tanpa pergantian air (P1); (c) sistem ZWD dengan mikroalga C. calcitrans dan B. megaterum tanpa pergantian air (P2). Berdasarkan hasil yang didapat, aplikasi bakteri nitrifikasi, mikroalga C. calcitrans dan B. megaterum mampu meningkatkan kineja sistem ZWD pada budidaya udang putih $L$. vannamei bersalinitas rendah. Selain itu, aplikasi bakteri nitrifikasi, mikroalga $C$. calcitrans dan $B$. megaterum pada sistem ZWD juga mampu meningkatkan laju pertumbuhan dan sintasan udang putih dibanding dengan kontrol. Kinerja pemeliharaan terbaik dijumpai pada sistem ZWD dengan aplikasi mikroalga $C$. calcitrans dan B. megaterum.
\end{abstract}




\section{INTRODUCTION}

White shrimp (Litopenaeus vannamei) is an endemic species of West Pacific ocean, from Peru to Mexico. The white shrimp was first introduced to Asia in 1978-1979, but began its commercial production in 1996 in Taiwan and China, then spread to Southeast and South Asia. In 2008, the worldwide production of paneid shrimp reached up to 3.399.105 tons and L. vannamei contributed 2.259 .183 tons or $67 \%$ of total production(Liao \& Chen, 2011). In 2015, the overall production all around the globe was estimated at 3.6 million tons and Indonesia contributed $16.5 \%$ or about 600.000 tons (GOAL, 2013).

The production of white shrimp in Indonesia recently is using a closed system, either traditional, semi-intensive, and intensive. According to Zhang et al. (2015) and Verdegem (2013), a closed system of aquaculture is potentially enrich the nutrient content in the rearing container. In closed aquaculture system, waste management in the rearing media was overcome using water exchange; but unfortunately, it may increase the nitrogen and phosphorus content which potentially triggers eutrophication in aquatic environment.

This eutrophication problem has been tried to be overcome in several ways, such as biofloc, recirculation aquaculture system (RAS), and zero water discharge. Application of certain technology might reduce water usage during the rearing period, depress pathogenic bacteria, improve water quality, and provide feed supplement (De Schryver et al., 2008; Martin et al., 2010; Zhao et al., 2012). The production enhancement of white shrimp was also done by expanding farm area. Recently, the central production of white shrimp only centered in coastal area which the salinity around $30 \mathrm{~g} / \mathrm{L}$. Biologically, the white shrimp has a wide tolerance for salinity fluctuation around 0.5-40 g/L (Gao et al., 2012), so that white shrimp culture activity might be done on wider rage area, not only in coastal area.

One of the applicable alternative on low salinity white shrimp rearing is zero water discharge (ZWD). The zero water discharge is an aquaculture system without water discharge. New water is only added to replace water loss due to evaporation. In this system, the microbe role is quite essential, especially chemoautotroph and heterotroph microbes, to control nutrient cycle, water quality, feed supplement supply, and inhibit pathogenic bacteria (Zhao et al., 2012; Suantika et al., 2015). The ZWD system is also applicable by increasing heterotroph bacteria in nutrient assimilation process using carbon addition in $\mathrm{C} / \mathrm{N}$ ratio manipulation to control inorganic $\mathrm{N}$ in culture media (Nootong et al., 2011; Gao et al., 2012; Panjaitan, 2010).

According to the description above, this study used low salinity for white shrimp rearing using zero water discharge through microbes manipulation (nitrification bacteria, microalgae, Bacillus megaterium, and Chaetoceros calcitrans). This study was aimed to evaluate zero water discharge performance by manipulating microbial loop in maintaining water quality, reducing pathogenic bacteria population (Vibrio sp.), and supporting the white shrimp growth in low salinity.

\section{MATERIALS AND METHODS}

\section{Activation and culture of nitrification bacteria $B$. megaterium and microalgae $C$. calcitrans}

Bacillus megaterium was cultured in nutrient broth (NB) media with dosage of $8 \mathrm{~g}$ for $1 \mathrm{~L}$ aquades, while $C$. calcitrans was cultured in Gullard media which contain mineral, phosphate, silicate, and natrium citrate in $1 \mathrm{~L}$ seawater with ratio $1 \mathrm{~mL}$ : $1 \mathrm{~mL}: 1 \mathrm{~mL}: 1 \mathrm{~mL}$. Meanwhile, the media that was used to culture nitrification bacteria was Nitrosomonas winogradsky $+\mathrm{CaCO}_{3}$ $0.5 \%$.

\section{White shrimp acclimatization}

The study used PL 10 phase of white shrimp fry which brought from PT. Suri Tani Pemuka, Indramayu, West Java. The white shrimp fries were acclimatized for seven days in fiber tank filled with $300 \mathrm{~L}$ of seawater at salinity of $30 \mathrm{~g} / \mathrm{L}$. During the acclimatization, the white shrimp fry was fed using micropellet (40\% protein content) about $10 \%$ of the fry biomass. The feeding frequency was four times a day, started at 8.00, $12.00,17.00$ and 21.00. Then the salinity was decreased from $30 \mathrm{~g} / \mathrm{L}$ to $2 \mathrm{~g} / \mathrm{L}$ in 10 days with decreasing speed of $2-3 \mathrm{~g} / \mathrm{L}$ each day. When salinity reached $4 \mathrm{~g} / \mathrm{L}$, the white shrimp fry was moved into $600 \mathrm{~L}$ nursery pond with $2 \mathrm{~g} / \mathrm{L}$ of salinity level. The nursery phase was done 2-3 weeks to adapt the experimental shrimp at the low salinity level to minimize mortality before they were moved into the to grow-out pond.

\section{The rearing system of white shrimp using zero water discharge}

The zero water discharge system consisted of several components. Those components were listed below : 
1. Tank sized $0.5 \mathrm{~m}^{2}$ (water volume $400 \mathrm{~L}$ )

2. Rearing media (salinity $2-3 \mathrm{~g} / \mathrm{L}$ )

3. $\mathrm{CaCO}_{3}$ gravel which was sunk to the bottom of the tank and cover it all.

4. Nitrification bacteria $\left(10^{6} \mathrm{CFU} / \mathrm{mL}\right)$ to control nitrification process

5. C. calcistrans $\left(10^{6}\right.$ cells $\left./ \mathrm{mL}\right)$ as nitrate/ orthophosphate absorbent and live feed and oxygen source.

6. B. megaterium $\left(10^{7} \mathrm{CFU} / \mathrm{mL}\right)$ to control nutrient assimilation

7. Aeration pump to supply oxygen

8. A 100 Watt heater to maintain the water temperature around $26 \pm 1{ }^{\circ} \mathrm{C}$

9. A siphon for cleaning organic material from the tank bottom.

The zero water discharge system scheme is shown in Figure 1.

\section{Experimental design}

This study was designed using complete randomized design consisted of three treatments and three replications. The treatments were control (K) (without bacteria and microalgae Chaetoceros calcitrans addition and water discharge), treatment 1 (P1) (nitrification bacteria, Bacillus megaterium, and Chaetoceros calcitrans addition, no water discharge), and treatment 2 (P2) (Bacillus megaterium and Chaetoceros calcitrans addition, no water discharge). The stock density was $160 \mathrm{ind} /$ tank equal to $400 \mathrm{ind} /$ $\mathrm{m}^{3}$ and the initial weight was $0.07 \pm 0.046 \mathrm{~g}$. During a 10 -weeks of rearing, the white shrimps were fed using commercial feed contained $40 \%$ protein three times a day about $10-5 \%$ of shrimp biomass. The uneaten feed and feces were siphoned out twice a week.

\section{Physical and chemical water quality measurement}

The water quality parameter consisted of dissolved oxygen, temperature, and $\mathrm{pH}$ were measured using Eutech digital instrument, whereas salinity was measured using SCT meter (accurate $0.1 \mathrm{~g} / \mathrm{L}$ ). Ammonium, nitrite, and nitrate were measured using $\mathrm{HACH}$ spectrophotometer (Nessler method) with 420, 520, 275, and 220 nm of wavelength (Rice et al., 2012). Dissolved oxygen, water temperature, $\mathrm{pH}$, and salinity were measured twice a week, while nitrite, nitrate, and ammonium were measured once a week.

\section{Microbiology and biology observation of white shrimp}

The water sample was taken each week to observe the amount of heterotroph bacteria, whereas the Vibrio sp. colony was observed twice a week using serial dilution method and spread plate technique (Cappucino \& Sherman, 2011). The media that was used to observed the Vibrio sp. bacteria colony was thiosulphate citrate bile salt agar (TCBSA). The media was selective for Vibrio sp., while the heterotroph bacteria was cultured in nutrient agar (NA). To count the bacteria colony on the culture media, the following equation was applied (Cappucino \& Sherman, 2011):

Total bacteria count $(\mathrm{CFU} / \mathrm{mL})=$

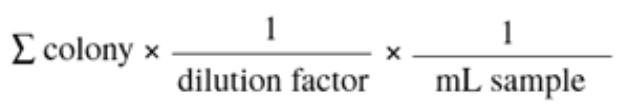

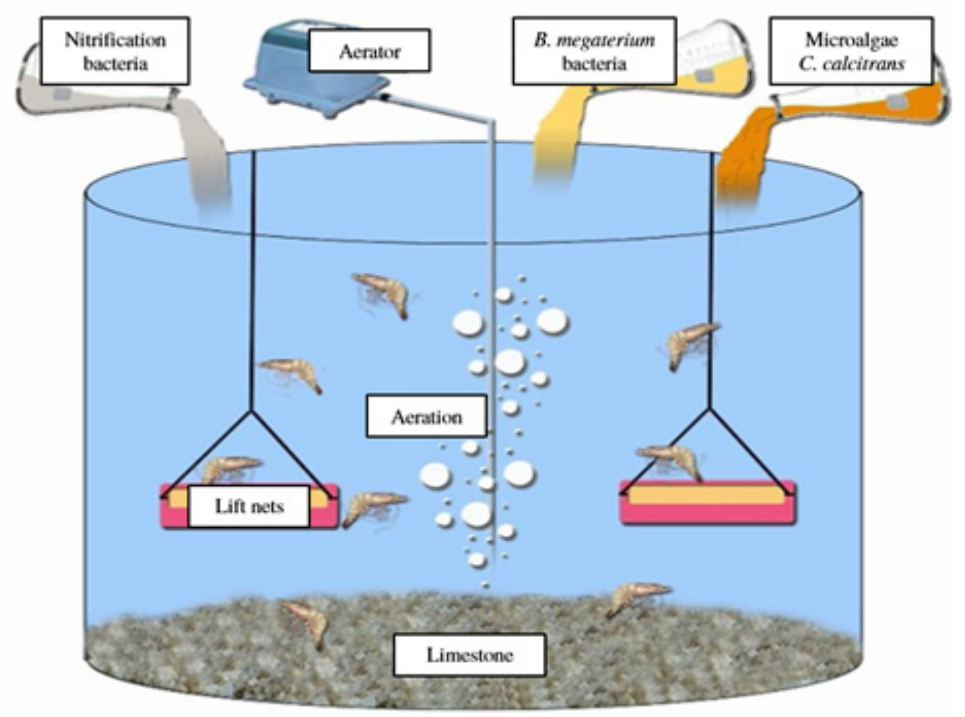

Figure 1. Grow-out scheme of white shrimp using zero water discharge 
The observed biological parameters of white shrimp, growth rate, survival rate, feed conversion ratio, final weight, and biomass, were calculated using the following equation:

Survival rate (\%)

$$
\mathrm{SR}(\%)=\frac{\mathrm{Nt}}{\mathrm{No}} \times 100
$$

Specific growth rate (\%/day)

$$
\mathrm{SGR}=\frac{\ln W \mathrm{t}-\ln \mathrm{Wo}_{\mathrm{o}}}{\mathrm{t}} \times 100
$$

Biomass

$$
\text { Biomass }=\mathrm{D} \times \mathrm{W}
$$

Feed conversion ratio

$$
\mathrm{FCR}=\frac{\mathrm{F}}{\mathrm{Wt}+\mathrm{D}-\mathrm{Wo}_{\mathrm{o}}}
$$

Note :

$\mathrm{N}_{0}$ : Initial population (ind)

$\mathrm{N}_{\mathrm{t}}$ : Final population (ind)

$\mathrm{W}_{\mathrm{t}}$ : Final weight $(\mathrm{g})$

$\mathrm{W}_{0} \quad$ : Initial weight $(\mathrm{g})$

$\mathrm{t}$ : Rearing period (day)

D : Stocking density (ind/tank)

$\hat{\mathrm{W}}$ : Average weight (g/ind)

F : Total feed (g)

Wt : Final weight $(\mathrm{g})$

D : Deceased weight (g)

$\mathrm{W}_{0}$ : Initial weight $(\mathrm{g})$

\section{Data analysis}

All the data were analyzed statistically using one way ANOVA test and descriptively using SPSS 17 to evaluate any differences on each treatment. The physical and chemical water quality parameters were analyzed using ANOVA, while the total count of heterotroph and Vibrio sp. were analyzed descriptively.

\section{RESULTS AND DISCUSSIONS}

\section{Conditioning zero water discharge system}

During the accustoming stage, the nitrification bacteria was able to oxidize ammonium from $9.84 \pm 1.22 \mathrm{mg} / \mathrm{L}$ to $1.71 \pm 0.43 \mathrm{mg} / \mathrm{L}$ on the fourth day of accustoming the ZWD system, so the ammonium oxidation rate was around 2.03 $\mathrm{mg} / \mathrm{L}$ per day. The ammonium oxidation become nitrite was seen from the increasing of nitrite concentration from $0.68 \pm 0.61 \mathrm{mg} / \mathrm{L}$ to 16.52 $\pm 1.77 \mathrm{mg} / \mathrm{L}$ on the fourth day and became 1.00 $\pm 0.78 \mathrm{mg} / \mathrm{L}$ after 16 days. The final product of nitrification from this ZWD system was nitrate. A nitrate accumulation at the end of the study reached up to $31.51 \pm 1.52 \mathrm{mg} / \mathrm{L}$ (Figure 2).

Conditioning of ZWD system was a crucial step before the rearing activity started. The nitrification bacteria was able to oxidize $\mathrm{NH}_{4}{ }^{+}$ and $\mathrm{NO}_{2}^{-}$which was toxic for aquatic organism, into $\mathrm{NO}_{3}$ which was less toxic. Result showed that ammonium oxidation was faster than nitrite oxidation. It was suspected caused by the growth of Nitrosomonas sp. which played an essential role in ammonium oxidation, was faster $( \pm 8$ hours) than the Nitrobacter $\mathrm{sp}$. ( \pm 12 hours) which plays crucial role in nitrite oxidation. After 72 hours, population of Nitrosomonas sp. was eight times over the Nitrobacter sp. (Gerardi, 2002).

Even though the nitrification process was achieved during the conditioning stage, however, a 16-day of conditioning required more considerations in zero water discharge system due to a longer period to rear white shrimp in

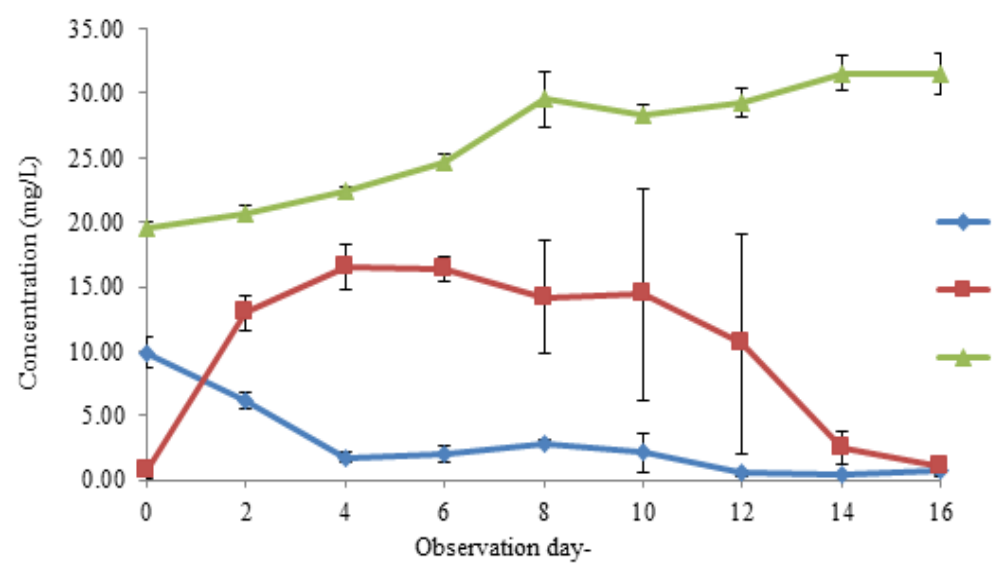

Figure 2. The nitrification bacteria performance in oxidizing ammonium and nitrite in ZWD system. 
Table 1. Average value of physical-chemical water quality

\begin{tabular}{llcc}
\hline $\begin{array}{c}\text { Physical-chemical water } \\
\text { quality parameter }\end{array}$ & \multicolumn{1}{c}{ Treatment } & Range & $\begin{array}{c}\text { Average } \pm \text { deviation } \\
\text { standard }\end{array}$ \\
\hline Dissolved oxygen (mg/L) & Control (K) & $6.24-8.89$ & $7, .37 \pm 0.70^{\mathrm{a}}$ \\
& Treatment 1 (P1) & $6.03-10.41$ & $7.45 \pm 1.00^{\mathrm{a}}$ \\
& Treatment 2 (P2) & $5.90-10.84$ & $7.64 \pm 1.17^{\mathrm{a}}$ \\
$\mathrm{pH}$ & Control (K) & $7.67-8.49$ & $8.01 \pm 0.24^{\mathrm{b}}$ \\
& Treatment 1 (P1) & $7.21-8.33$ & $7.70 \pm 0.32^{\mathrm{a}}$ \\
& Treatment 2 (P2) & $7.64-8.54$ & $7.94 \pm 0.24^{\mathrm{ab}}$ \\
Ammonium (mg/L) & Control (K) & $0.90-3.69$ & $2.44 \pm 0.78^{\mathrm{a}}$ \\
& Treatment 1 (P1) & $1, .33-3.82$ & $2.43 \pm 0.76^{\mathrm{a}}$ \\
& Treatment 2 (P2) & $0.90-4.66$ & $2.98 \pm 1.03^{\mathrm{a}}$ \\
Nitrite (mg/L) & Control (K) & $0.73-25.99$ & $8.29 \pm 9.36^{\mathrm{b}}$ \\
& Treatment 1 (P1) & $0.11-6.65$ & $2.19 \pm 1.64^{\mathrm{a}}$ \\
Nitrate (mg/L) & Treatment 2 (P2) & $0.61-16.09$ & $5.32 \pm 5.25^{\mathrm{a}}$ \\
& Control (K) & $13.44-43.34$ & $24.04 \pm 10.04^{\mathrm{a}}$ \\
& Treatment 1 (P1) & $31.30-58.72$ & $41.76 \pm 7.87^{\mathrm{b}}$ \\
& Treatment 2 (P2) & $16.13-38.77$ & $22.04 \pm 6.84^{\mathrm{a}}$ \\
\hline
\end{tabular}

Note: Different superscripts in the same column showed significant difference statistically $(\mathrm{P}<0.05) ;(\mathrm{K}=$ without bacteria and microalgae addition with $10-20 \%$ v/v of water discharge; P1 = nitrification bacteria, B. megaterium, and $C$. calcitrans addition, without water discharge; $\mathrm{P} 2=B$. megaterium and $C$. calcitrans addition, without water discharge)

one single production cycle. One of the solution to overcome this weakness was to optimize the activation of nitrification bacteria for oxidating ammonium and nitrite. It might be preferred to culture the bacteria in a stock before inoculate to the ZWD system.

\section{Physical and chemical water quality parameter}

The average range of $\mathrm{DO}$ and $\mathrm{pH}$ during 10 weeks of rearing period is shown in Table 1. The dissolved oxygen changes was affected by aeration and respiration rate of white shrimp, whereas $\mathrm{pH}$ was affected by excretion rate and decomposition process of organic material. According to statistical analysis, the dissolved oxygen concentration was not significantly different $(\mathrm{P}>0.05)$, while $\mathrm{pH}$ level showed significant difference $(\mathrm{P}<0.05)$ between $\mathrm{P} 1$ and $\mathrm{K}$ treatment, but it did not significantly different with P2.

Dissolved oxygen concentration during 10 weeks of rearing period was still in an optimal range to support white shrimp growth. According to Boyd (2010), dissolved oxygen concentration should be $3 \mathrm{mg} / \mathrm{L}$ or more to maintain feed consumption and proper growth. Moreover, the study by Chakravarty et al. (2016) stated that dissolved oxygen in the white shrimp rearing environment was range between $4.4-8.6 \mathrm{mg} / \mathrm{L}$. Meanwhile, $\mathrm{pH}$ level in overall was quite stable, even though statistically it showed significant difference, but it was still tolerable for white shrimp. According to Utojo (2008), a normal pH level for white shrimp was around 7.5-8.5. A stable $\mathrm{pH}$ level could achieved by $\mathrm{CaCO}_{3}$ addition on the bottom of the tank as $\mathrm{pH}$ buffer and substrate for nitrification bacteria, so that the $\mathrm{pH}$ level drop due to nitrification and decomposition could be avoided.

Although there was no significant difference in $\mathrm{NH}_{4}{ }^{+}$concentration, however the $\mathrm{NH}_{4}{ }^{+}$ concentration in P2 and P1 were higher than that of control. It was caused by a higher feed amount in P1 (654.80 g) and P2 (695.26 g) than control $(429.70 \mathrm{~g})$. The differences in the given feed amount caused the different in growth and survival rate (Table 2). The higher feed amount, the organic material accumulation will be higher as well, so that $\mathrm{NH}_{4}{ }^{+}$will be accumulated (FAO, 2014).

The nitrite concentration in the control, $\mathrm{P} 1$, and $\mathrm{P} 2$ treatment were $0.73-25.99 \mathrm{mg} / \mathrm{L}, 0.11-6.65$ $\mathrm{mg} / \mathrm{L}$, and $0.61-16.09 \mathrm{mg} / \mathrm{L}$, respectively. During the culturing period, nitrite concentration showed an increase at second to fourth week in the $\mathrm{K}$ and $\mathrm{P} 2$ treatment, while the $\mathrm{P} 1$ treatment tended to be more stable. Statistically, nitrite concentration was significantly different among treatments $(\mathrm{P}<0.05)$. In P1 treatment, nitrite concentration was quite more stable because of the nitrification bacteria addition, so that the $\mathrm{NO}_{2}^{-}$and $\mathrm{NO}_{3}{ }^{-}$oxidation was run normally. Similar result did not occur in P2 and $\mathrm{K}$ treatment, which $\mathrm{NO}_{2}-$ was increasing until 
the fourth week. The $\mathrm{NO}_{2}$ - increase presumably due to lack of nitrification bacteria in the $\mathrm{K}$ and P2 treatment, therefore the nitrification process was going slowly.

The final step of nitrification process is nitrate $\left(\mathrm{NO}_{3}{ }^{-}\right)$, which is the final product of ammonium and nitrite oxidation. $\mathrm{NO}_{3}$ concentration during the rearing period of white shrimp in low salinity showed escalation tendency from the beginning to the end of the study. It presented that the nitrification process was occurred in each treatment because the nitrification bacteria is categorized as opportunist bacteria. The highest $\mathrm{NO}_{3}$ concentration was found in $\mathrm{P} 1$ treatment (31.30-58.72 $\mathrm{mg} / \mathrm{L})$, then followed by treatment $\mathrm{K}$ (13.43-43.34 mg/L) and P2 (16.13-38.77 $\mathrm{mg} / \mathrm{L})$. Statistical analysis showed that the nitrate concentration was significantly different among treatment $(\mathrm{P}<0.05)$. Nitrification bacteria addition in treatment P1 created a high level of $\mathrm{NO}_{3}{ }^{-}$ indicated that the nitrification process was going swiftly compared to the $\mathrm{K}$ and $\mathrm{P} 2$ treatment. The accumulation of $\mathrm{NO}_{3}{ }^{-}$was also indicated that the microalgae C. calcitrans was poorly developed and nitrate assimilation by $C$. calcitrans was also depressed.

In term of microbial-based aquaculture, microbe is literally play essential roles in controlling $\mathrm{N}$-inorganic and water quality improvement. Those were affected by several factors, such as microbe species, feed protein content, $\mathrm{C} / \mathrm{N}$ ratio, and other abiotic factor. Gerardi (2002) stated that nitrification bacteria utilization in aquaculture system to oxidize ammonium and nitrite were affected by alkalinity, $\mathrm{pH}$, temperature, salinity, organic and inorganic material, substrate, and light intensity. Meanwhile, Bacillus megaterium or heterotroph bacteria utilization in controlling inorganic nitrogen in aquaculture system was strictly affected by feed protein content and $\mathrm{C} / \mathrm{N}$ ratio manipulation through nitrogen addition (Nootong et al., 2011; Bosma \& Verdegem, 2011).

Even though ammonium was increase at certain week, rose beyond the optimal range approximately 2.44-3.95 mg/L (Lin \& Chen, 2001), it was still below the lethal concentration (LC) 50 after 48 hours in salinity of $10 \mathrm{mg} / \mathrm{L}$ which was $39.72 \mathrm{mg} / \mathrm{L}(2.09 \mathrm{mg} / \mathrm{L}$ of unionized ammonia-N). The $\mathrm{pH}$ level also affected ammonium toxicity in white shrimp. In Table 1, the overall range of $\mathrm{pH}$ level was around 7.2-8.5 which was below 9. The $\mathrm{pH}$ level $<9$ is considered harmless because it did not convert ammonium $\mathrm{NH}_{4}{ }^{+}$to $\mathrm{NH}_{3}$ which certainly toxic to white shrimp (Gonzalex-Felix, 2007).

Nitrite is a toxic compound to white shrimp other than ammonium so that it is necessarily controlled to lower the nitrite in rearing media. The nitrite concentration in control and P2 treatment passed beyond the tolerable range of low salinity white shrimp rearing which was $>6.1$ $\mathrm{mg} / \mathrm{L}$. According to Furtado et al. (2016), nitrite concentration over 2.5 and $10 \mathrm{mg} / \mathrm{L}$ at salinity of 8 and $24 \mathrm{mg} / \mathrm{L}$ was considered feasible for white shrimp. Meanwhile nitrate is a nitrogen compound which is less toxic compared to ammonium and nitrite. The tolerable range of nitrate for white shrimp rearing was $177 \mathrm{mg} / \mathrm{L}$ at salinity of $23 \mathrm{~g} / \mathrm{L}$ (Furtado et al., 2014).

\section{Heterotroph and Vibrio sp. bacteria population dynamic in low salinity of white shrimp rearing}

The population dynamics of heterotroph bacteria in low salinity of white shrimp culture is shown in Figure 3. The total amount of heterotroph in $\mathrm{K}, \mathrm{P} 1$, and $\mathrm{P} 2$ treatment were $10^{2}-10^{5} \mathrm{CFU} / \mathrm{mL}, 10^{1}-10^{5} \mathrm{CFU} / \mathrm{mL}, 10^{3}-10^{5}$

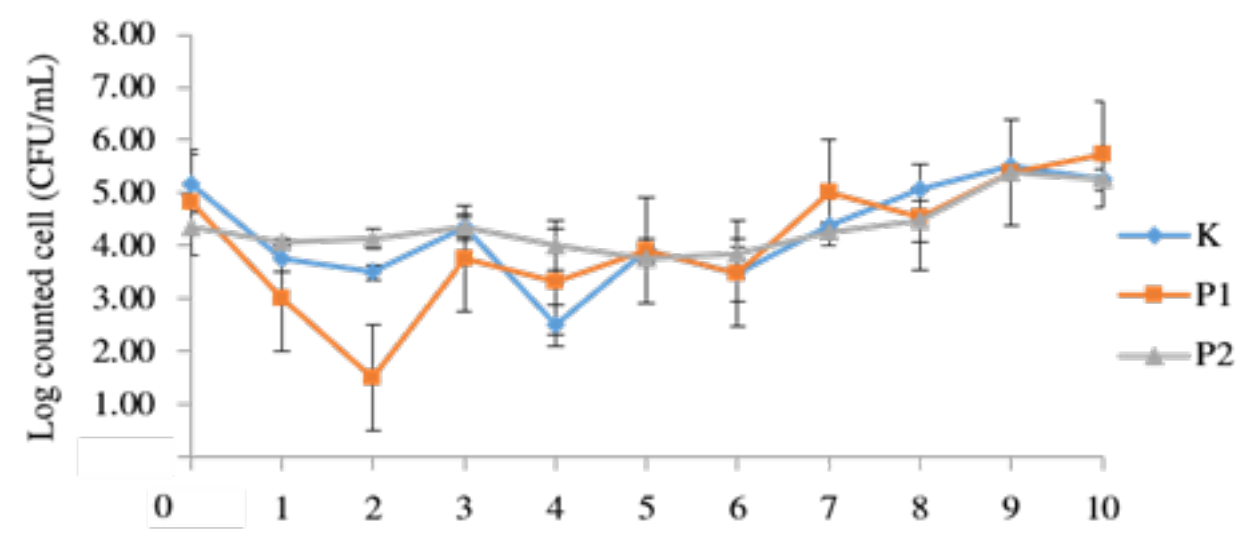

Figure 3. Population dynamics of heterotroph at low salinity of white shrimp culture. $\mathrm{K}=$ without bacteria and microalgae addition with $10-20 \% \mathrm{v} / \mathrm{v}$ of water discharge; $\mathrm{P} 1=$ nitrification bacteria, B. megaterium, and $C$. calcitrans addition, without water discharge; $\mathrm{P} 2=B$. megaterium and $C$. calcitrans addition, without water 
Table 2. Final weight, specific growth rate, survival rate, biomass, and feed conversion ratio of white shrimp at low salinity.

\begin{tabular}{|c|c|c|c|}
\hline Parameter & $\mathrm{K}$ & $\mathrm{P} 1$ & $\mathrm{P} 2$ \\
\hline Final weight (g/ind) & $2.28 \pm 0.21^{\mathrm{a}}$ & $3.35 \pm 0.51^{\mathrm{b}}$ & $3.67 \pm 0.20^{\mathrm{b}}$ \\
\hline Specific growth rate (\%/day) & $4.97 \pm 0.31^{\mathrm{a}}$ & $5.52 \pm 0.21^{\mathrm{b}}$ & $5.65 \pm 0.08^{b}$ \\
\hline Survival rate $(\%)$ & $73.96 \pm 10.28^{\mathrm{a}}$ & $83.96 \pm 7,19^{\mathrm{ab}}$ & $94.79 \pm 2.81^{b}$ \\
\hline Biomass & $267.63 \pm 11.48^{\mathrm{a}}$ & $446.60 \pm 36.67^{b}$ & $555.97 \pm 37.01^{\mathrm{c}}$ \\
\hline Feed conversion ratio & $1.61 \pm 0.07^{\mathrm{b}}$ & $1.47 \pm 0.08^{\mathrm{b}}$ & $1.25 \pm 0.07^{\mathrm{a}}$ \\
\hline
\end{tabular}

$\mathrm{CFU} / \mathrm{mL}$, respectively. At the end of the culture, there was an increase on heterotroph bacteria population, but the statistical analysis showed no significant difference $(\mathrm{P}>0.05)$. At the end of the culture, heterotroph bacteria population reached up to $10^{5} \mathrm{CFU} / \mathrm{mL}$. It was assumed that there was nutrient accumulation from feces and uneaten feed which is acted as carbon and nitrogen source to support heterotroph bacteria growth (CastilloSoariano et al., 2013).

The population dynamics of Vibrio spp. at low salinity white shrimp culture is presented in Figure 4. Total population of Vibrio spp. in K, P1, and P2 treatment were $10^{1}-10^{3} \mathrm{CFU} / \mathrm{mL}, 10^{1}-10^{3} \mathrm{CFU} /$ $\mathrm{mL}, 10^{1}-10^{3} \mathrm{CFU} / \mathrm{mL}$, respectively. At the end of the culture, population of Vibrio spp. decreased in P1 and P2 treatment, but instead increased in $\mathrm{K}$ treatment. Based on statistical analysis, the population of Vibrio spp. in each treatment was not significantly different $(\mathrm{P}>0.05)$.

Total population of Vibrio spp. for each treatment were in the similar range $\left(10^{1}-10^{3}\right.$ $\mathrm{CFU} / \mathrm{mL}$ ). The number of population was below quorum sensing and pathogenic number was $>10^{4}$ $\mathrm{CFU} / \mathrm{mL}$. It was presumably caused by the low salinity (2-3 g/L). On the contrary, Vibrio spp. was considered to survived at higher salinity $(>10$ $\mathrm{g} / \mathrm{L}$ ) which was in line with Abraham and Debasis (2009) who stated that Vibrio spp. existence was strictly affected by salinity variation. A lower salinity (4-9 g/L) that potentially depressed Vibrio spp. Was about $\leq 10^{3} \mathrm{CFU} / \mathrm{mL}$, while higher salinity tended to increase Vibrio spp. population up to $10^{4}-10^{5} \mathrm{CFU} / \mathrm{mL}$.

Vibrio spp. is a threatening pathogen and mainly found in marine aquaculture species, such as crustaceans and molluscs. The Vibrio spp. is frequently pathogenic and causes huge loss in marine culture species. Vibriosis is a common disease caused by V. harveyi, V. parahaemolyticus, V. alginolyticus, V. anguillarum, V. vulnificus, and other species. The other disease caused by Vibrio spp. is white gut disease (WGD) which inhibits white shrimp growth (Chatterjee \& Haldar, 2012; Gunalan et al., 2014).

\section{Biological parameter of white shrimp}

The measured biological parameters (biomass, specific growth rate, survival rate, final weight, and feed conversion rate) were shown in Table 2 .

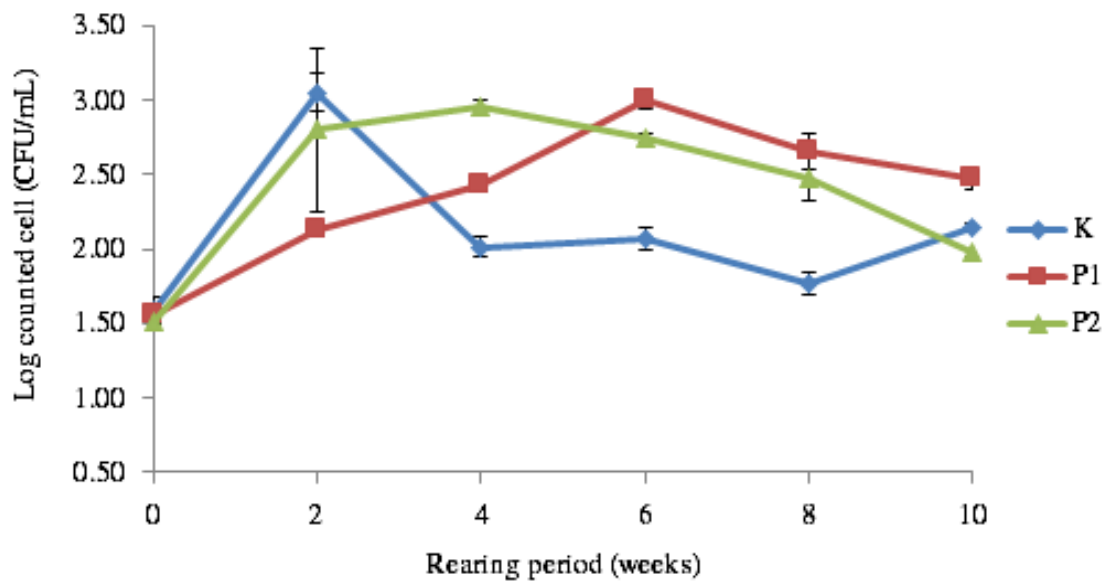

Figure 4. Population dynamic of Vibrio at low salinity white shrimp culture. $\mathrm{K}=$ without bacteria and microalgae addition with $10-20 \%$ v/v of water discharge; $\mathrm{P} 1=$ nitrification bacteria, $B$. megaterium, and $C$. calcitrans addition, without water discharge; $\mathrm{P} 2=B$. megaterium and $C$. calcitrans addition, without water discharge. 
According to statistical analysis, biomass, specific growth rate, and final weight were significantly different $(\mathrm{P}<0.05)$.

The P2 treatment resulted higher biomass, specific growth rate, and final weight. The ZWD performance on white shrimp rearing at low salinity reached the highest performance in P2 treatment. It was assumed that the combination between Bacillus megaterium and C. calcitrans stimulated floc formation. The floc formation was seen through water color changes that became brownish green, while the $\mathrm{K}$ and $\mathrm{P} 1$ treatment was quite clear. The floc formed in P2 treatment could acted as additional feed and nutrition for supporting shrimp growth.

According to Choo and Caipang (2015), water color changing from dark brownish-green to greenish-brown influenced by feed amount showed that there was a transition from microalgae to bacteria as biofloc component. Even though P1 treatment was also added Bacillus megaterium and $C$. calcitrans, unfortunately, the microalgae production was not optimal. It was because of the microalgae reduced the direct light intensity, then nitrification bacteria growth was inhibited and decreased nitrification rate. Beside organic material, light is one of the inhibiting factor in nitrification process (Gerardi, 2002; Merbt et al., 2012; Vergara et al., 2016).

Generally, white shrimp reared at low salinity resulted in lower growth compared to white shrimp reared at higher salinity $(30 \mathrm{~g} / \mathrm{L})$. Suantika et al. (2015) described that white shrimp reared using zero water discharge at salinity of 30 $\mathrm{g} / \mathrm{L}$ and stocking density of $400 \mathrm{ind} / \mathrm{m}^{3}$ produced $8.24 \pm 0.84 \mathrm{~g}$ in final weight and specific growth rate $7.7 \pm 011 \% /$ day. Compared the previous statement, the present study produced almost 3.67 $\pm 0.20 \mathrm{~g}$ in final weight and specific growth rate $5.65 \pm 0.08 \% /$ day.

Low growth of white shrimp reared at low salinity was assumed due to enormous energy demand in ion and amino acid osmolarity in body tissues for osmoregulation process. It was in line with Shinji et al. (2012) who stated that white shrimp reared at salinity $3 \mathrm{~g} / \mathrm{L}$ would synthesized certain amino acid (L-serine and lysine) which suspected to regulate osmoregulation process. Roy et al. (2010) also presented that rearing media modification using magnesium and potassium fertilizer was further effective compared with feed modification technique in producing high growth and survival rate, and stable osmoregulation. Therefore, a major consideration must be placed on feed modification technique using certain amino acid and also utilization of several particular minerals to support white shrimp rearing at low salinity.

Production performance using zero water discharge is not only observed through the growth parameter but also the feed conversion ratio and survival rate. The feed conversion ratio and survival rate of present study is presented in Table 2. Satistical analysis showed that feed conversion ratio and survival rate showed were significantly difference among treatments $(\mathrm{P}<0.05)$. The lowest FCR was found in P2 treatment $(1.25 \pm$ $0.07)$, followed by $\mathrm{P} 1(1.47 \pm 0.08)$, and $\mathrm{K}$ (1.61 $\pm 0.07)$. The highest survival rate was seen in $\mathrm{P} 2$ $(94.79 \pm 2.81)$, followed by P1 $(83.96 \pm 7.19 \%)$ and $\mathrm{K}(73.96 \pm 10.28 \%)$.

The FCR value is essential in white shrimp rearing because it indicates feed amount to produce $1 \mathrm{~kg}$ of white shrimp biomass. The lower FCR value the more profitable because the highest cost component in shrimp culture is feed. In another study using zero water discharge at the densitity of $>200 \mathrm{ind} / \mathrm{m}^{3}$, resulted FCR 1.2-1.5 (Maia et al., 2016; Browdy et al., 2014), that were still in line with the present study (FCR 1.25-1.47). In addition, survival rate value also determines the superiority of the ZWD application in practice. The study using ZWD technology at low salinity resulted higher survival rate (84-95\%) compared with that of conventional system (74\%).

\section{CONCLUSION}

In conclusion, $\mathrm{P} 2$ treatment (B. megaterium and microalgae $C$. calcitrans addition) presented better result in supporting growth, survival, and feed conversion ratio of white shrimp at low salinity. The ZWD system in $\mathrm{P} 2$ treatment resulted final weight $3.67 \mathrm{~g}$; specific growth rate $5.65 \% /$ day; survival rate $94.79 \%$; and feed conversion ratio 1.25 .

\section{ACKNOWLEDGMENT}

We expressed our gratitude to PT. Suri Tani Pemuka Indramayu who supported this study by providing white shrimp fry and Sekolah Ilmu dan Teknologi Hayati, Bandung Institute of Technology who facilitate us during the study.

\section{REFERENCES}

Abraham TJ, Debasis S. 2009. Influence of salinity and management practices on the shrimp 
Penaeus monodon production and bacterial counts of modified extensive brackishwater ponds.Turkish Journal of Fisheries and Aquatic Sciences 9: 91-9.

Bosma RH, Verdegem MCJ. 2011. Sustainable aquaculture in ponds: Principles, practices and limits. Livestock Science 139: 58-68

Boyd CE. 2012. Dissolved-Oxygen Concentrations in pond Aquaculture. Global Aquaculture Alliance: Australia.

Browdy CL, Hargreaves J, Tung $\mathrm{H}$ and Avnimelech Y. 2014. Biofloc Technology and Shrimp Disease Workshop. The Aquaculture Engineering Society, Copper Hill, VA USA. Hlm. 83-153.

Cappucino JG, Sherman N. 2011. Microbiology A Laboratory Manual. San Fransisco: Benjamin Cummings.

Chatterjee S, Haldar S. 2012. Vibrio related diseases in aquaculture and development of rapid and accurate identification methods. Journal Marine Science Research and Development 2155-9910.

Castillo-Soriano FA, Ibarra-Junquera V, Escalante-Minakata P, Mendoza-Cano O, Ornelas-Paz JJ, Almanza-Ramírez JC, MeyerWillerer AO. 2013. Nitrogen dynamics model in zero water exchange, low salinity intensive ponds of white shrimp, Litopenaeus vannamei at Colima, Mexico. Latin American Journal of Aquatic Research 41: 68-79.

Choo HX, Caipang CMA. 2015. Biofloc technology (BFT) and its application towards improved production in freshwater tilapia culture. Aquaculture, Aquarium, Conservation \& Legislation-International Journal of the Bioflux Society 8: 3.

Chakravarty MS, Ganeseh PRC, Amarnath D, Sudha BS, Babu TS. 2016. Spatial variation of water quality parameter of shrimp Litopenaeus vannamei culture ponds at Narasapupeta, Kajuluru and Kaikavolu villages of East Godavari district, Andhra Pradesh. International Journal of Fisheries and Aquatic Studies 4: 390-395.

De Schryver P, Crab R, Defoirdt T, Boom N, dan Verstraete W. 2008. The basics of bio-flocs technology: The added value for aquaculture. Aquaculture 277: 125-137

Erlandson M, Cory N, Kohler S, Bishop K. 2010. Direct and indirect effects of increasing dissolved organic carbon levels on $\mathrm{pH}$ in lakes recovering from acidification. Journal of Geophysical Research 115: 1-8.
[FAO] Food Agricultural Organization. 2014. Small-scale aquaponic food production. Integrated and plant farming [Fisheries and Aquaculture Technical Paper]. Roma, Italia: FAO.

Furtado PS, Campos BR, Serra FP, Klosterhoff M, Romano LA, Wasielesky W. 2014. Effects of nitrate toxicity in the Pacific white shrimp, Litopenaeus vannamei, reared with biofloc technology (BFT). Aquaculture International 23: 315-327.

Furtado PS, Valenzuela MAJ, Fuentes GR, Campos BR, Wasielesky W, Gaxiola G. 2016. Chronic effect of nitrite on the rearing of the white shrimp Litopenaeus vannamei in two salinities. Journal of Marine and Freshwater Behavior and Physiology 49:201-211.

[GOAL] Global Aquaculture Alliance.2013. Shrimp production survey, Issues and Challenges: 2013. https://www. aquaculturealliance.org/goal13 anderson.pdf. [2 April 2018].

Gao L, Shan HW, Zhang TW, Bao WY, Ma S. 2012. Effects of carbohydrate addition on Litopenaeus vannamei intensive culture in a zero-water exchange system. Aquaculture 342-343: 89-96.

Gao W, Tan B, Mai K, Chi S, Liu H, Dong X, Yang Q. 2012. Profiling of differentially expressed genes in hepatopancreas of white shrimp Litopenaeus vannamei exposed to long-term low salinity stress. Aquaculture 364-365:186-191.

Gerardi MH. 2002. Nitrification and Denitrification in the Active Sludge Process. New York: Wiley-Interscience.

Gonzalex-Felix ML, Gomez-Jimmenez S, PeresVelazquez M, Davis DA, Velaszco-Ramenos, JG. 2007. Nitrogen budget for a low salinity, zero-water exchange culture system: effect of dietary protein level on the performance of Litopenaeus vannamei (Boone). Aquaculture Research 38: 798-808.

Gunalan B, Soundarapandian P, Anand T, Kotiya AS, Simon NT. 2014. Disease occurrence in Litopenaeus vannamei shrimp culture systems in different geographical regions of India. International Journal of Aquaculture 4: 24-28.

Lin YC, Chen JC. 2001. Acute toxicity of ammonia on Litopenaeus vannamei (Boone) juveniles at different salinity levels. Journal of Experimental Marine Biology dan Ecology 259: 109-119.

Liao IC, Chien YH. 2011. The Pacific white 
shrimp, Litopenaues vannamei, in Asia: the world's most widely cultured alien crustacean. Springer Series in Invasion Ecology 6:489-519.

Li EL, Zeng CC, Chen X, Yu N, Lai Q, Qin JW. 2007. Growth, body composition, respiration and ambient ammonia nitrogen tolerance of the juvenile white shrimp, Litopenaeus vannamei, at different salinities. Aquaculture 265: 385-390.

Li J, Tan B, Mai K. 2009. Dietary probiotic Bacillus OJ and isomaltooligosaccharides influence the intestine microbial population, immune responses and resistance to white spot syndrome virus in shrimp Litopenaeus vannamei. Aquaculture 291: 35-40.

Nootong K, Pavasant P, Powtongsook S. 2011. Effects of Organic Carbon Addition in Controlling Inorganic Nitrogen Concentrations in a Biofloc System. Journal of the World Aquaculture Society 42: 339-446.

Martin CIM, Eding EH, Verdergem MCJ, Heinsbroek LTN, Schneider O, Blancheton JP, Roqued E, Orbcastej dan Berreth JAJ. 2010. New developments in recirculating aquaculture systems in Europe: A perspective on environmental sustainability. Aquaculture Engineering 43: 83-93.

Merbt SN, Stahl DA, Casamayor EO, Marti E, Nicol GW, Prosse JI. 2012. Differential photoinhibition of bacterial and archaeal ammonia oxidation. FEMS Microbiology Letters 327:41-46.

Margabandu V, Ramamurthy D. 2013. Recent farming practices for culturing sustainable Pacific white shrimp, Penaeus vannamei. International Journal of Science dan research 4: 2.

Maia EP, Modesto GA, Brito LO, Galvez AO, Gesteira TCV. 2016. Intensive culture system of Litopenaeus vannamei in commercial ponds with zero water exchange and addition of molasses and probiotics. Revista de Biologia Marina y Oceanografia 51: 61-67.

Panjaitan P. 2010. Shrimp culture of Penaeus monodon with zero water exchange model (ZWEM) using molase. Journal of Coastal Development 14: 35-44.

Rice EW, Baird RB, Eaton AD, Clesceri LS.
2012. Standard Methods for the Examination of Water and Wastewater, $22^{\text {nd }}$ Edition. USA: American Public Health Association.

Roy LA, Davis DA, Saoud IP, Boyd CA, Pine HJ, Boyd CE. 2010. Shrimp Culture in inland low salinity water. Review in Aquaculture 2: 191-208.

Schuler DJ, Boarman GD, Kuhn DD, Flick GJ. 2010. Acute toxicity ammonia and nitrite to Pacific white shrimp, Litopenaues vannamei, at low salinities. Journal of the World Aquaculture Society 41: 438-446.

Shinji J, Okutsu T, Jayasankar V, Jasmani S, Wilder MN. 2012. Metabolism of amino acids during hyposmotic adaptation in the whiteleg shrimp, Litopenaeus vannamei. Amino Acids 43: 1945-1954.

Suantika G, Lumbantoruan G, Muhammad H, Aziza FFN, Aditiawati P. 2015. Performance of zero water discharge (ZWD) system with nitrifying bacteria and microalgae Chaetoceros calcitrans components in super intensive white shrimp Litopenaeus vannamei culture. Aquaculture Research and Development 6: 359.

Utojo, Tangko A.M. 2008. Status, Masalah, dan Alternatif Pemecahan Masalah pada Pengembagan Budidaya Udang Vannamei (Litopenaeus vannamei) di Sulawesi Selatan. Media Akuakultur 3: 118-125.

Verdegem MCJ. 2013. Nutrient discharge from aquaculture operations in function of system design and production environment. Review in Aquaculture 5: 158-171.

Vergara C, Munoz R, Campos JL, Seeger M dan Jeison D. 2016. Influence of light intensity on bacterial nitrifying activity in algal-bacterial photobioreactors and its implications for microalgae-based wastewater treatment. International Biodeterioration and Biodegradation 114: 116-121.

Zhao P, Huang J, Wang XH, Song XL, Yang CH, Zhang XG, Wang GC. 2012. The application of bioflocs technology in high-intensive, zero exchange farming systems of Marsupenaeus japonicas. Aquaculture 354-355: 97-106

Zhang Y, Bleeker A, Liu J. 2015. Nutrient discharge from China's aquaculture industry and associated environmental impact. Environmental Research Letter 10: 1-14. 